\title{
Differential Effects of Insulin-like Growth Factor I and Growth Hormone on Developmental Stages of Rat Growth Plate Chondrocytes In Vivo
}

Ernst B. Hunziker, Jeannine Wagner, and Jürgen Zapf *

M. E. Müller Institute for Biomechanics, University of Bern, 3010 Bern; and *Division of Endocrinology and Metabolism, Department of Medicine, University Hospital, 8091 Zürich, Switzerland

\begin{abstract}
Skeletal growth depends upon enchondral ossification in growth plate cartilage, within which chondrocytes undergo well defined stages of maturation. We infused IGF-I or growth hormone (GH), two key regulators of skeletal growth, into hypophysectomized rats and compared their effects on growth plate chondrocyte differentiation using qualitative and quantitative autoradiography, stereology, and incident light fluorescence microscopy. Stem cell cycle time was shortened from 50 to 15 and $8 \mathrm{~d}$ after treatment with IGF-I and GH, respectively. Proliferating cell cycle time decreased from 11 to 4.5 and $3 \mathrm{~d}$, and duration of the hypertrophic phase decreased from 6 to 4 and $2.8 \mathrm{~d}$. Average matrix volume per cell at each differentiation stage was similar for normal, hormone-treated, and untreated hypophysectomized groups. Mean cell volume and cell height were significantly reduced by hypophysectomy at the proliferative and hypertrophic stages, but were restored to physiological values by IGF-I and GH. In contrast, cell productivity, i.e., increases in cell volume, height, and matrix production per unit of time, did not reach normal values with either IGF-I or GH, and this parameter was inversely proportional to cell cycle time or phase duration.

IGF-I and GH are thus capable of stimulating growth plate chondrocytes at all stages of differentiation, albeit to variable degrees with respect to individual cell activities. Although it is generally accepted that GH acts at both the stem and proliferating phases of chondrocyte differentiation, our data represent the first evidence in vivo that IGF-I is also capable of stimulating stem cells. (J. Clin. Invest. 1994. 93:1078-1086.) Key words: insulin-like growth factor I • growth hormone • cartilage - differentiation - bone growth
\end{abstract}

\section{Introduction}

Both IGF-I and growth hormone $(\mathrm{GH})^{1}$ stimulate growth plate activity and thus promote bone elongation $(1,2)$. Chondrocyte performances implicated in this process include cell proliferation, matrix production, and, above all, cell-controlled phenotype modulation (hypertrophy) $(3,4)$. The mechanisms by

Address correspondence to Dr. Ernst B. Hunziker, M. E. Müller Institute for Biomechanics, University of Bern, P.O. Box 30, 3010 Bern, Switzerland.

Received for publication 7 September 1993 and in revised form 15 November 1993.

1. Abbreviations used in this paper: $\mathrm{GH}$, growth hormone; rh, recombinant human; RHT, ruthenium hexaammine trichloride.

J. Clin. Invest.

(c) The American Society for Clinical Investigation, Inc. 0021-9738/94/03/1078/09 \$2.00

Volume 93, March 1994, 1078-1086 which IGF-I and GH act upon growth plate chondrocytes are largely unknown. Studies addressing this question have used mainly cultured cells or subpopulations of these (5-7). Early investigations with cartilage explants from hypophysectomized rats led to the somatomedin hypothesis of Salmon and Daughaday $(8,9)$. They postulated that $\mathrm{GH}$ did not act directly on sulfate incorporation into cartilage, but that its effects were mediated by a serum factor (somatomedin) produced by the liver (10). Although this proposal was supported by many studies (for review see reference 11 ), others disclosed a direct action of $\mathrm{GH}$ on growth plate chondrocytes $(12,13)$. This led to a modification of the somatomedin hypothesis. It includes the possibility that GH may act via local production of IGF-I (1416), i.e., by an autocrine/paracrine mechanism. Further data, again derived from in vitro investigations using chondrocyte subpopulations, have indicated that IGF-I influences chondrocytes principally during the proliferative phase by stimulating clonal expansion, whereas GH acts selectively upon stem (resting) cells as a differentiation factor, the ensuing effect on proliferation being triggered by local production of IGF-I (dual effector theory) $(5,17,18)$.

To date, analysis of IGF-I/GH effects in vivo have been restricted to the measurement of bulk parameters, such as growth plate width, matrix production $\left({ }^{35} \mathrm{~S}\right.$ incorporation), and cell proliferative activity $\left(\left[{ }^{3} \mathrm{H}\right]\right.$ thymidine incorporation) $(1,12,18,19)$. Effects upon individual chondrocyte activities at various stages of differentiation in vivo have not been addressed, and it has therefore not been possible to assess their relative contributions.

It was the aim of this study to elucidate the physiological mechanisms by which IGF-I and GH act upon individual chondrocytes of the growth plate at the various stages of differentiation using the hypophysectomized rat model. The effects of continuously infused IGF-I and GH upon cell proliferative activity, cell height and volume, and net matrix production were investigated for each phase of the chondrocyte life cycle using stereological, autoradiographic, and fluorescence microscopy techniques. Both IGF-I and GH were found to stimulate all phases of chondrocyte differentiation, but IGF-I was less effective than $\mathrm{GH}$.

\section{Methods}

To minimize the effects of signaling substances physiologically present in the chondrocyte's natural environment, 35-d-old male Wistar rats were hypophysectomized by a postpyramidal surgical approach (performed by R. Cortesi, Ciba-Geigy AG, Basel, Switzerland). 2 wk after surgery ( this interval being necessary to allow for body weight stabilization and control), osmotic minipumps (Alzet ${ }^{\oplus} 2002$; Scientific Marketing, London, UK) were implanted subcutaneously in the abdominal region, and signal substances were infused continuously for $8 \mathrm{~d}$ at a rate of $1 \mu \mathrm{l} / \mathrm{h}$. Recombinant human ( $\mathrm{rh}$ ) IGF-I ( $12.5 \mu \mathrm{g} / \mu \mathrm{l}$ in $0.1 \mathrm{M}$ acetic acid; Ciba-Geigy AG) and rhGH ( $8.3 \mathrm{mU} / \mu \mathrm{l}$ in saline; Novo-Nordisk, 
Gentofte, Denmark) were used at doses which in an earlier study had been shown to yield maximal effects with respect to body weight gain and increase in tibial epiphyseal height. When the maximal chosen dose of rhGH was exceeded, growth plate height did not remain stable but decreased, whereas at higher concentrations of rhIGF-I, the animal mortality rate increased drastically, probably because of hypoglycemia (20).

Four groups of six animals were investigated: two hypophysectomized and hormone-treated groups; one hypophysectomized group infused with saline served as a control. An age-matched group of normal rats was included for comparative purposes as a standard for physiological chondrocyte activity levels.

Growth rate determination and matrix production. Growth rates were measured between days 5 and 8 (or days 0 and 8 for hypophysectomized controls) after beginning the infusion. Preliminary studies have indicated that maximal steady state growth effects are achieved by the second day. Animals were injected subcutaneously with $15 \mathrm{mg}$ of calceine (Chassot \& Cie AG, Koeniz, Switzerland) per kilogram of body weight, 4 or $8 \mathrm{~d}$ (hypophysectomized controls) before killing.

For the autoradiographic determination of proliferating cell pool sizes and border line delineation between cell activity phases (i.e., growth plate zones), animals were injected intraperitoneally with $1 \mu \mathrm{Ci}$ of $\left[{ }^{3} \mathrm{H}\right]$ thymidine (Amersham International, Buckinghamshire, UK) per kilogram of body weight $1 \mathrm{~h}$ before killing.

To estimate the glycan content of cartilage matrix in the various experimental groups, required as a basis for comparison with the relevant stereologic volume estimators, two additional animals per experimental condition were injected subcutaneously with a total of $2 \mathrm{mCi}$ of ${ }^{35} \mathrm{SO}_{4}{ }^{2-} / \mathrm{kg}$ body $\mathrm{wt}$, given at 8 - $\mathrm{h}$ intervals during the final $3 \mathrm{~d}$ before killing. Tissue was then processed for quantitative autoradiography (see below).

Serum parameters and tissue sampling. Upon termination of each experiment, animals were anesthesized with Innovar Vet ${ }^{\oplus}$ (PitmanMoore, Inc., Washington Crossing, $\mathrm{NJ} ; 0.2 \mathrm{ml} / 100 \mathrm{~g}$ body wt i.m.) and were bled by aortic puncture. Blood samples were collected on ice and centrifuged for $15 \mathrm{~min}$ at $4^{\circ} \mathrm{C}(1,500 \mathrm{~g})$, and serum was stored at $-20^{\circ} \mathrm{C}$. The serum was used for the determination of glucose, IGF-I, testosterone, and free thyroxine levels (see below). Liver, heart, thymus, spleen, and epidydimal fat pads were weighed. The serum levels of IGF-I were measured by radioimmunoassay $(21,22)$. Testosterone and free thyroxine levels were determined by standard radioimmunoassay procedures, and glucose levels were determined by a glucose analyzer (model 23A; Yellow Springs Instrument Co., Yellow Springs, $\mathrm{OH}$ ).

Soft tissues were removed from the left and right tibiae to allow measurement of frontal and sagittal diameters at the level of the proximal tibial growth plates (used for the estimation of growth plate reference volume). Then, the growth plates were sawed into sagittal slices, each of which was divided into a number of tissue blocks. These were numbered and, according to a systematic random sampling protocol, three blocks per leg were selected for stereological measurements (for details see 23 and 24 ). One tissue slice per leg was used for measuring growth rate.

Tissue processing for stereology, fluorescence microscopy, and autoradiography. Freshly excised tissue slices were placed immediately in fixative solution for further processing under a stereomicroscope. Tissue for stereological analysis was glutaraldehyde fixed in the presence of ruthenium hexaammine trichloride (RHT) (Johnson Matthey and Brandenberger, Zürich, Switzerland), was postfixed in osmium tetroxide, was dehydrated in ethanol, and was embedded in Epon 812.1- $\mu \mathrm{m}$ sections were cut on an ultramicrotome ultracut E Leica (Leica, Vienna, Austria), each block being cut vertically (parallel to the longitudinal bone axis), and section direction systematically varied in the horizontal plane (IUR sections). Details of these protocols have been reported elsewhere $(3,24)$.

Tissue blocks for ${ }^{3} \mathrm{H}$-autoradiography were glutaraldehyde fixed in the absence of RHT; they were not postfixed. Further processing was as detailed above. Tissue blocks used for quantitative ${ }^{35} \mathrm{~S}$-autoradiography were processed by freeze substitution and low temperature embed- ding to avoid absorption of beta rays by RHT and to minimize loss of proteoglycans. After cryofixation in liquid nitrogen, they were freeze substituted in methanol and embedded in Lowicryl ${ }^{\circledR} \mathrm{K} 4 \mathrm{M}$ (Chemische Werke Lowi, GmbH, Waldkraiburg, Germany) (25). Semithin (1- $\mu \mathrm{m})$ sections were immersed in a Kodak NTB2 emulsion (diluted $1: 1$ with distilled water), were maintained in the dark for $4 \mathrm{wk}\left(\mathrm{at}+4^{\circ} \mathrm{C}\right)$, were developed with D19 (Kodak) developer, were fixed, and were stained with toluidine blue $\mathrm{O}$.

Tissue sections for fluorescence analysis (incident light fluorescence microscopy) were fixed in $40 \%$ ( $\mathrm{vol} / \mathrm{vol}$ ) ethanol for $3 \mathrm{~d}$ at ambient temperature, were dehydrated in ethanol, and were embedded in methyl methacrylate. $10-\mu \mathrm{m}$ sections were cut on a Jung rotatory microtome (Leica) and were analyzed unstained in an incident light fluorescence microscope (Leitz, Wetzlar, Germany).

Stereological quantitation of cell activities. Growth plate tissue was subdivided into stem (germinal or reserve) cell, proliferating, and hypertrophic zones, defined according to data derived from $\left[{ }^{3} \mathrm{H}\right]-$ thymidine autoradiography, which permits delineation of the upper and lower limits of the proliferating cell pool.

The following basic stereological estimators were determined: mean cell volume $(\overline{\mathrm{v}}[\mathrm{c}])$, mean matrix volume per cell $(\overline{\mathrm{m}}[\mathrm{c}])$, mean projected horizontal diameter $\left(\overline{\mathrm{X}}\left[90^{\circ}\right]\right)$, mean cell height $\left(\overline{\mathrm{X}}\left[0^{\circ}\right]\right)$, and the number of chondrocytes $(n[\mathrm{c}])$ within a zone (differentiation stage) and per column. Methods used have been described in detail elsewhere $(3,23,24,26)$. Cell productivity parameters, namely net matrix production, cell volume, and cell height increase per unit of time, were estimated by dividing $\overline{\mathrm{m}}(\mathrm{c}), \overline{\mathrm{v}}(\mathrm{c})$, and $\overline{\mathrm{X}}\left(0^{\circ}\right)$, respectively, by the cell cycle time (or phase duration) in hours.

Quantitation of ${ }^{35} \mathrm{~S}$ incorporation was performed by grain counting methods in the interterritorial matrix compartments using a $5 \times 30$ $\mu \mathrm{m}$ frame.

Longitudinal growth rates were obtained using the fluorochrome (calceine) labeling technique and incident light fluorescent microscopic analysis $(24,27)$.

Section thickness was controlled using an interference phase-contrast microscope (Leitz).

Cell kinetics. Axial cell columns are defined as the functional units of longitudinal bone growth $(28,29)$. Within these units, cell production and elimination rates as well as growth plate height, are constant over the short period of time (4 d) during which growth was measured. Cell elimination (and production) rate was obtained by dividing the daily growth rate by the mean height $\left(\overline{\mathrm{X}}\left[0^{\circ}\right]\right)$ of the terminal chondrocyte (28). The duration of hypertrophic phase activity and the mean cycle time for stem (germinal) and proliferating chondrocytes were determined according to the method of Kember (28) and Hunziker and Schenk (3).

Data are graphically summarized in Figs. 1 and 2, and key numerical values are given in the appropriate legends. Statistical significances $(P<0.05)$ between experimental groups were estimated using the Mann-Whitney $U$ test and unpaired, two-tailed $t$ tests.

\section{Results}

Serum levels of glucose, free thyroxine, testosterone, and IGF-I are represented in Table I. The levels of glucose, free thyroxine, and testosterone were significantly lowered in hypophysectomized rats as compared with values in normal animals. No changes in these parameters were observed during IGF-I or GH infusion. Serum IGF-I decreased to $6 \%$ of normal rat levels after hypophysectomy. IGF-I infusion restored IGF-I serum levels to normal, and $\mathrm{GH}$ to $50 \%$ of the physiological value.

Bulk parameters. Changes in body and organ weights are generally used as indicators of growth. In the $\mathrm{NaCl}$-infused hypophysectomized group, body (Table II) and organ (data not presented) weights did not increase. IGF-I- and GHtreated animals gained 19 and $33 \mathrm{~g}$, respectively, during the 8-d 
A

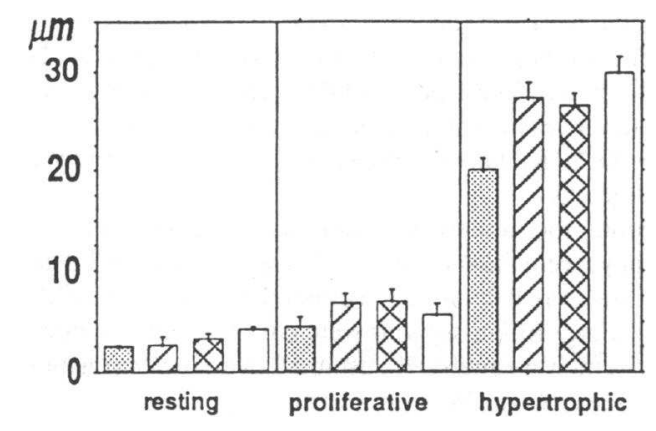

C Net Matrix Production Per Cell

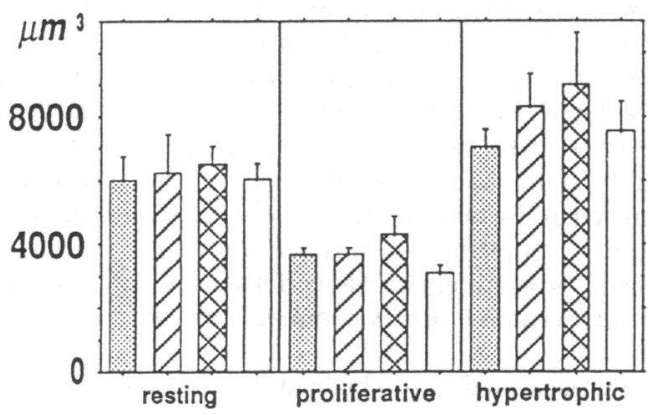

B Cell Volume

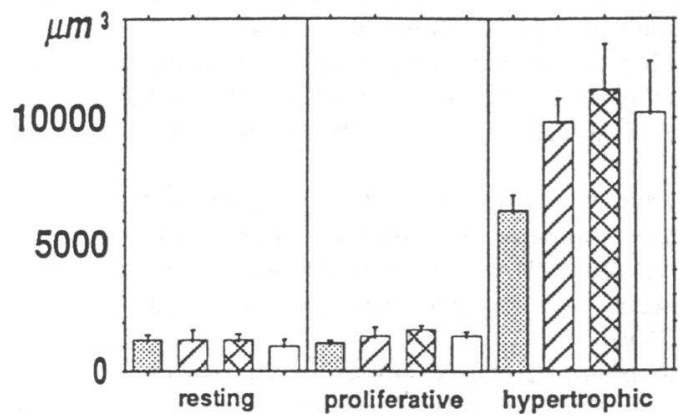

Figure 1. Chondrocyte structural parameters. (A) Cell height. (Resting phase) Mean cell heights did not differ significantly between NaCl (3.9 $\mu \mathrm{m})$, IGF-I $(3.9 \mu \mathrm{m})$, GH $(4.7 \mu \mathrm{m})$, and normal rat $(5.9 \mu \mathrm{m})$ groups. (Proliferative phase) Mean cell height in the $\mathrm{NaCl}$ group $(6.8 \mu \mathrm{m})$ was significantly less than that in either the IGF-I $(9.8 \mu \mathrm{m}), \mathrm{GH}(9.9 \mu \mathrm{m})$, or normal animal $(8.9 \mu \mathrm{m})$ groups; the latter three did not differ significantly from one another. (Hypertrophic phase) Mean terminal cell height in the $\mathrm{NaCl}$ group $(19.5 \mu \mathrm{m})$ was significantly less than that in either the IGF-I $(27.3 \mu \mathrm{m})$, GH $(26.5 \mu \mathrm{m})$, or normal rat $(29.8 \mu \mathrm{m})$ groups; the latter three did not differ significantly from one another. $(B)$ Mean cell volume. (Resting phase) Mean cell volume did not differ significantly between the four experimental groups $\left(1,270 \mu \mathrm{m}^{3}[\mathrm{NaCl}], 1,280\right.$ $\mu \mathrm{m}^{3}$ [ IGF-I], 1,290 $\mu \mathrm{m}^{3}$ [GH], 1,000 $\mu \mathrm{m}^{3}$ [normal rats]). (Proliferative phase) Mean cell volume in the $\mathrm{NaCl}$ group $\left(1,160 \mu \mathrm{m}^{3}\right)$ was significantly smaller than that in either the IGF-I $\left(1,590 \mu \mathrm{m}^{3}\right), \mathrm{GH}\left(1,680 \mu \mathrm{m}^{3}\right)$, or normal animal $\left(1,400 \mu \mathrm{m}^{3}\right)$ groups; the latter three did not differ significantly from one another. (Hypertrophic phase) Mean cell volume in the $\mathrm{NaCl}$ group $\left(6,370 \mu \mathrm{m}^{3}\right)$ was significantly smaller than that in either the IGF-I $\left(9,890 \mu \mathrm{m}^{3}\right), \mathrm{GH}\left(11,140 \mu \mathrm{m}^{3}\right)$, or normal rat $\left(10,240 \mu \mathrm{m}^{3}\right)$ groups; the latter three did not differ significantly from one another. $(C)$ Net matrix production per cell. Mean net matrix volumes produced per cell did not differ significantly from one another with respect either to experimental group or cell activity phase (resting cells: $6,000 \mu \mathrm{m}^{3}[\mathrm{NaCl}], 6,210 \mu \mathrm{m}^{3}$ [IGF-I], $6,520 \mu \mathrm{m}^{3}$ [GH], $6,030 \mu \mathrm{m}^{3}$ [normal rats]; proliferative chondrocytes: $3,670 \mu \mathrm{m}^{3}$ [ $\mathrm{NaCl}$ ], $4,410 \mu \mathrm{m}^{3}$ [IGF-I], $4,290 \mu \mathrm{m}^{3}$ [GH], $3,060 \mu \mathrm{m}^{3}$ [normal rats]; hypertrophic chondrocytes: 7,030 $\mu \mathrm{m}^{3}$ [ $\mathrm{NaCl}$ ] , 8,280 $\mu \mathrm{m}^{3}$ [IGF-I], 8,990 $\mu \mathrm{m}^{3}$ [GH], 7,540 $\mu \mathrm{m}^{3}$ [normal rats]). $\square, \mathrm{NaCl}$ group (hypophysectomized control); $\square$, IGF-I group; a, GH group; and $\square$, Normal (unhypophysectomized) rat group.

infusion period (Table II); weights of the heart, spleen, liver, kidneys, and thymus increased similarly (data not presented).

More specific indicators of growth include the height of the entire growth plate and of the individual zones, each of which represents a differentiation-specific cell pool (Table II and Fig. $3)$. Proliferating and hypertrophic zone heights were significantly reduced in hypophysectomized control rats, as was total growth plate height (Fig. 3 and Table II). In IGF-I-treated animals, total growth plate height was similar to that in normal rats, despite dramatically differing growth rate activities ( Table II). Proliferating cell pool height was greater, and hypertrophic zone height was smaller than in normal animals. GH caused a significantly greater increase in the height of proliferating and hypertrophic zones and of the entire growth plate, but physiological growth rates were not attained. Given that growth rates were clearly highest in normal animals, these data confirm our previous finding (3) that growth plate height, frequently used as a bulk parameter to assess longitudinal growth activity (the so-called "tibia test" of Greenspan et al. [19]), is not a reliable indicator of bone growth rate.

Cell structural characteristics. Mean cell volume and height (Fig. 1) are known to ultimately determine the final outcome of longitudinal growth. These structural estimators were reduced in hypophysectomized animals, most notably the mean terminal cell height and volume attained during hypertrophy; mean cell height was also reduced during the proliferative differentiation stage (Figs. 4 and 5). Mean net matrix volume per cell, lateral cell diameter (data not presented), and the structural estimators describing stem (resting) cells remained unaltered (Fig. 1).

Surprisingly, both mean cell height and volume were restored to physiological values in the proliferating and hypertro- 
A Cycle Time (Phase Duration)

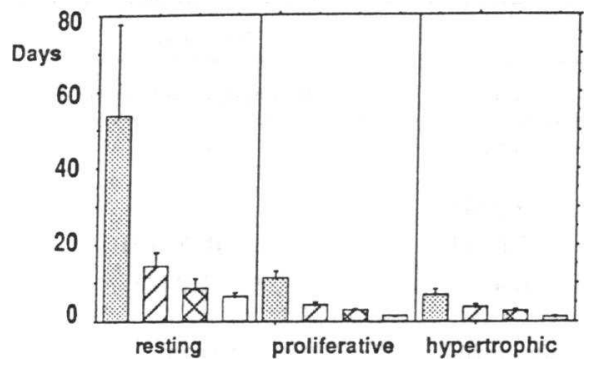

C Cell Turnover/Column

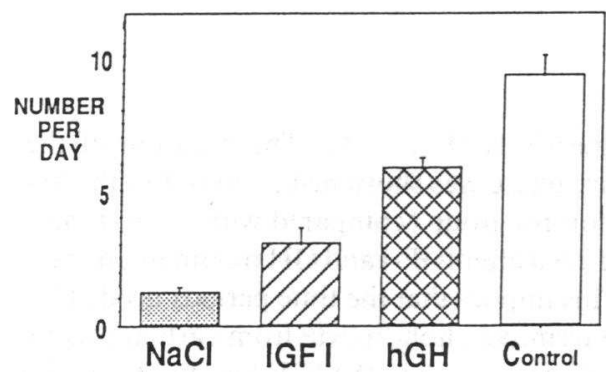

E $\Delta$ Cell Volume / Hour

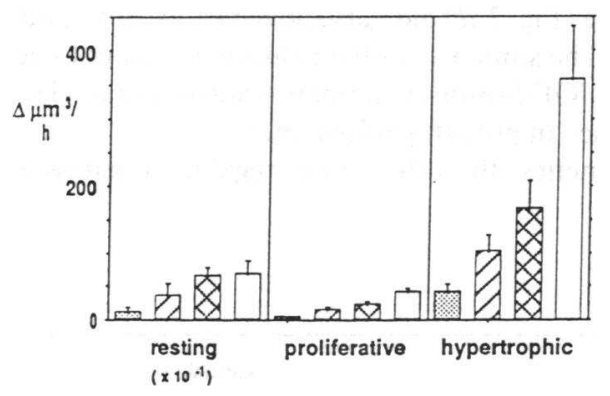

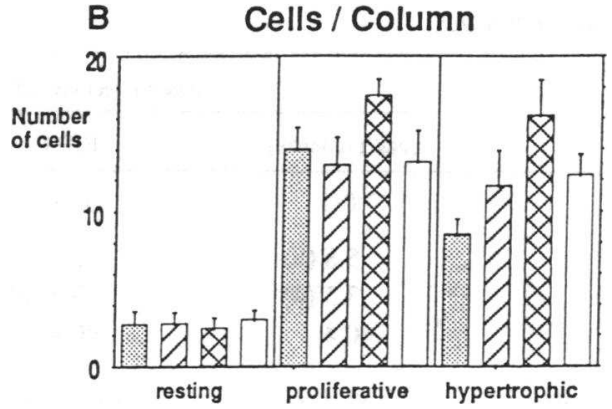

D $\Delta$ Cell Height / Hour

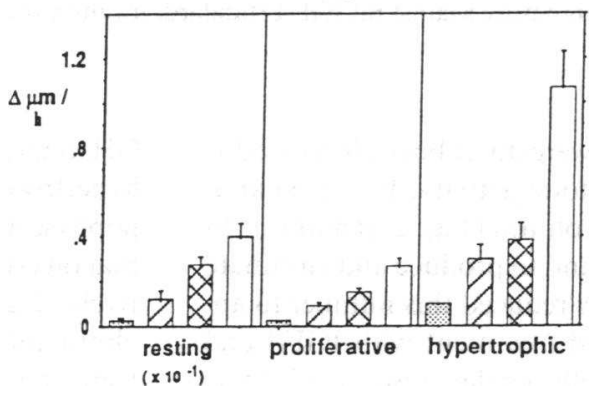

F Matrix Production / Hour

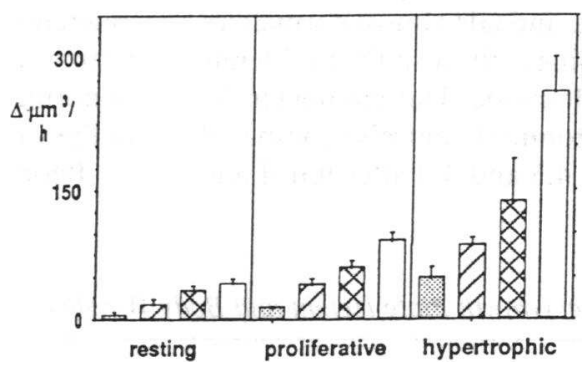

Figure 2. Chondrocyte activity and kinetics. $(A)$ Cycle time (phase duration). Resting cell cycle times were significantly shorter in stimulated groups ( 15 $\mathrm{d}$ [IGF-I], $8 \mathrm{~d}$ [GH]) than in the $\mathrm{NaCl}$ group ( $50 \mathrm{~d}$ ), but they were not normalized ( $6 \mathrm{~d}$ [ normal rats]). All differences were significant $(P<0.05)$. Similar findings were observed for both the proliferative cell cycle time ( $11 \mathrm{~d}$ [ $\mathrm{NaCl}$ ], $4.5 \mathrm{~d}$ [ IGF-I], $3 \mathrm{~d}$ [GH], $1.4 \mathrm{~d}$ [normal rats]) and for hypertrophic activity phase duration $(6 \mathrm{~d}[\mathrm{NaCl}$ ], $4 \mathrm{~d}$ [ IGFI], $2.8 \mathrm{~d}$ [GH] , and $1.2 \mathrm{~d}$ [normal rats]). ( $B$ ) Cells per column. The number of resting cells per cell column was similar in all experimental groups ( 2.5

[NaCl], 2 [IGF-I], 2 [GH], and 2.5 [normal rats]). The number of proliferative chondrocytes per column was the same (i.e., 14) for $\mathrm{NaCl}$, IGF-I, and normal rat groups; in the GH group, a significantly higher number was attained (18). The number of hypertrophic chondrocytes per column was significantly smaller (8) in the $\mathrm{NaCl}$ group than in the others, and the GH group had the highest number (16); IGF-I and normal rat groups had the same number (12). $(C)$ Cell turnover/column. Cell turnover (the number of chondrocytes produced and eliminated per day and per column ) roughly paralleled the daily growth rates and differed significantly between all experimental groups $(1[\mathrm{NaCl}]$, 3 [IGF-I], 6 [GH], and 10 [normal rats]). (D) Cell height increase per hour. Cell height increase per hour $(\mu \mathrm{m} / \mathrm{h})$ differed significantly between the various experimental groups. Resting cell: $0.003(\mathrm{NaCl}), 0.011$ (IGF-I), 0.025 (GH), and 0.041 (normal rats). Proliferative:

$0.026(\mathrm{NaCl}), 0.091$ (IGF-I), $0.138(\mathrm{GH})$, and 0.248 (normal rats). Hypertrophic: 0.1 ( NaCl), 0.3 (IGF-I), 0.4 (GH), and 1.1 (normal rats). $(E)$ Cell volume increase per hour. Cell volume increase $\left(\mu \mathrm{m}^{3} / \mathrm{h}\right)$ differed significantly between the various experimental groups. Resting cell: $1(\mathrm{NaCl}), 3.6$ (IGF-I), $6.7(\mathrm{GH})$, and 7.0 (normal rats). Proliferative: 4 ( NaCl), 15 (IGF-I), $24(\mathrm{GH})$, and 42 (normal rats). Hypertrophic: $44(\mathrm{NaCl}), 103(\mathrm{IGF}-\mathrm{I}), 166(\mathrm{GH})$, and 356 (normal rats). $(F)$ Matrix production per cell and hour. Matrix production per cell and hour $\left(\mu \mathrm{m}^{3} /\right.$ cell $/ \mathrm{h}$ ) differed significantly between the various experimental groups. Resting cell: 5 ( $\left.\mathrm{NaCl}\right), 17$ (IGF-I), 34 (GH), and 42 (normal rats). Proliferative: $14(\mathrm{NaCl}), 41$ (IGF-I), 60 (GH), and 91 (normal rats). Hypertrophic: 49 ( NaCl), 86 (IGF-I), 134 (GH), and 262 (normal rats).

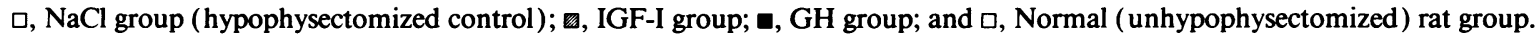

phic activity phases after treatment with either IGF-I or GH (Figs. 1, 4, and 5), whereas mean lateral diameter (data not shown) and mean matrix volume per cell (Fig. 1) were similar in all experimental groups. Quantitative ${ }^{35}$ S-autoradiography of cartilage matrix revealed that grain densities and thus proteoglycan concentration did not differ significantly either between proliferating and hypertrophic activity phases or between the different experimental groups (data not presented). Hence, no dilution effects existed, and stereological matrix volume measurements reflected true matrix mass increases.

Cell kinetics and cell productivity. Major differences in cell activity levels were found between the various treatment 


\begin{tabular}{|c|c|c|c|c|}
\hline & \multicolumn{3}{|c|}{ Hypophysectomized rats } & \multirow{2}{*}{$\frac{\text { Normal rats }}{\text { (Unhypophysectomized) }}$} \\
\hline & $\mathrm{NaCl}$ (control) & IGF-I & GH & \\
\hline & $(\%)$ & (\%) & $(\%)$ & (\%) \\
\hline Glucose (mmol/liter) & $5.8(8)$ & $5.5(4)$ & $6.5(4)$ & $13.2(7)$ \\
\hline Free thyroxine ( $\mathrm{pmol} /$ liter $)^{*}$ & $3.5(4)$ & $3.3(2)$ & $2.6(11)$ & $48.5(13)$ \\
\hline $\begin{array}{l}\text { Testosterone }(\mathrm{nmol} / \text { liter }) \\
\text { ir. IGF-I }(\mathrm{ng} / \mathrm{ml})\end{array}$ & $<0.4$ & $<0.4$ & $<0.4$ & $1.0(2)$ \\
\hline $\begin{array}{l}\text { (determined against rat standard })^{\ddagger} \\
\text { ir. IGF-I }(n g / m l) \\
\quad(\text { expressed in human }\end{array}$ & $106(12)$ & $1813(13)$ & $887(10)$ & $1771(5)$ \\
\hline nanogram equivalents) ${ }^{\ddagger}$ & $24(18)$ & $412(13)$ & $202(9)$ & $403(5)$ \\
\hline
\end{tabular}

Mean values for six animals are represented; coefficients of error are given in parentheses. Determinations were made upon termination of experiments. * Chondrocyte hypertrophy required the presence of persisting minimum serum levels of free thyroxine (both in vitro [7,42,43] and in vivo [44, 45]); such a condition pertained in hypophysectomized rats. ${ }^{\ddagger}$ Recombinant human IGF-I is 4-5 times more potent than rat IGF-I when determined by radioimmunoassay against rat IGF-I standard. ir., immunoreactive.

groups (Fig. 2). These differences were due, above all, to modulations in the cell cycle time (mitotic activity, Fig. $2 A$ ) and, hence, in the kinetics of an axial column (Fig. 2, $B$ and $C$ ). In normal rats, cell columns were found to produce and eliminate 10 cells per day. Hypophysectomy reduced this number to approximately one cell per day, and treatment with IGF-I and GH increased it to three and six cells per day, respectively (Fig. $2 C$ ). The basis for these effects upon axial (linear) cell production and elimination rates lies in the dramatic influence of signal substances upon cell proliferation and productivity. In the resting ( stem) cell phase, the prolonged cycle times induced by hypophysectomy (from 6 [in normal rats] to $\sim 50 \mathrm{~d}$ ) were considerably shortened by IGF-I and GH treatment (to 15 and $8 \mathrm{~d}$, respectively) (Fig. $2 A$ ). IGF-I thus has a significant stimulatory effect upon stem cell mitosis, and $\mathrm{GH}$ almost normalizes this activity. The effects upon cycling activity in the proliferating cell pool were somewhat less dramatic. This parameter decreased from $11 \mathrm{~d}$ in hypophysectomized controls (compared with $1.4 \mathrm{~d}$ in normal animals) to 4.5 and $3 \mathrm{~d}$ after IGF-I and
GH treatment, respectively (Fig. $2 A$ ). The duration of the hypertrophic activity phase was shortened from $6 \mathrm{~d}$ in the hypophysectomized control group (compared with $1.2 \mathrm{~d}$ in normal rats) to 4.0 and $2.8 \mathrm{~d}$ after IGF-I and GH treatment, respectively (Fig. $2 \mathrm{~A}$ ). This implies that the time periods needed for elimination of one terminal chondrocyte from cartilage tissue were $16 \mathrm{~h}$ in the $\mathrm{NaCl}$ group, $8 \mathrm{~h}$ in the IGF-I group, $4 \mathrm{~h}$ in the $\mathrm{GH}$ group, and $2.5 \mathrm{~h}$ in normal animals.

Given the proportional similarity in chronological effects observed during the chondrocyte differentiation cascade under the various experimental conditions, it is not surprising that the growth fractions (number of proliferating cells divided by the total number of cells per column) did not differ significantly from one another. The absolute cell pool size at each differentiation stage (Fig. $2 B$ ) did vary, however, except in the resting cell phase. The similarity of the columnar cell pool size in normal rats and IGF-I-infused animals is surprising in view of the vast difference in growth performance.

Besides cell kinetics, the other main regulatory pathway

Table II. Longitudinal Growth Rate: Growth Plate Height and Body Weights

\begin{tabular}{|c|c|c|c|c|}
\hline & \multicolumn{3}{|c|}{ Hypophysectomized rats } & \multirow{2}{*}{$\frac{\text { Normal rats }}{\text { (Unhypophysectomized) }}$} \\
\hline & $\mathrm{NaCl}$ (control) & IGF-I & GH & \\
\hline & (\%) & (\%) & $(\%)$ & (\%) \\
\hline \multicolumn{5}{|l|}{ Body wt of animals $(g)$} \\
\hline at onset of experiment* & $128(2)$ & $126(2)$ & $123(3)$ & $241(1)$ \\
\hline upon termination of experiment & $121(2)$ & $145(2)$ & $156(4)$ & $302(2)$ \\
\hline Longitudinal growth rate $(\mu m / d)$ & $31(5)$ & $92(7)$ & $163(2)$ & $284(4)$ \\
\hline Total growth plate height $(\mu m)$ & $244(2)$ & $380(4)$ & $484(2)$ & $401(3)$ \\
\hline \multicolumn{5}{|l|}{ Height $(\mu m)$ of } \\
\hline resting zone & $33(4)$ & $27(11)$ & $31(4)$ & $36(5)$ \\
\hline proliferating zone & $97(2)$ & $146(3)$ & $174(2)$ & $128(3)$ \\
\hline hypertrophic zone & $114(2)$ & $207(3)$ & $279(1)$ & $237(1)$ \\
\hline
\end{tabular}

Mean values for six animals are represented; coefficients of error are given in parentheses. * Onset, at the beginning of infusion. 

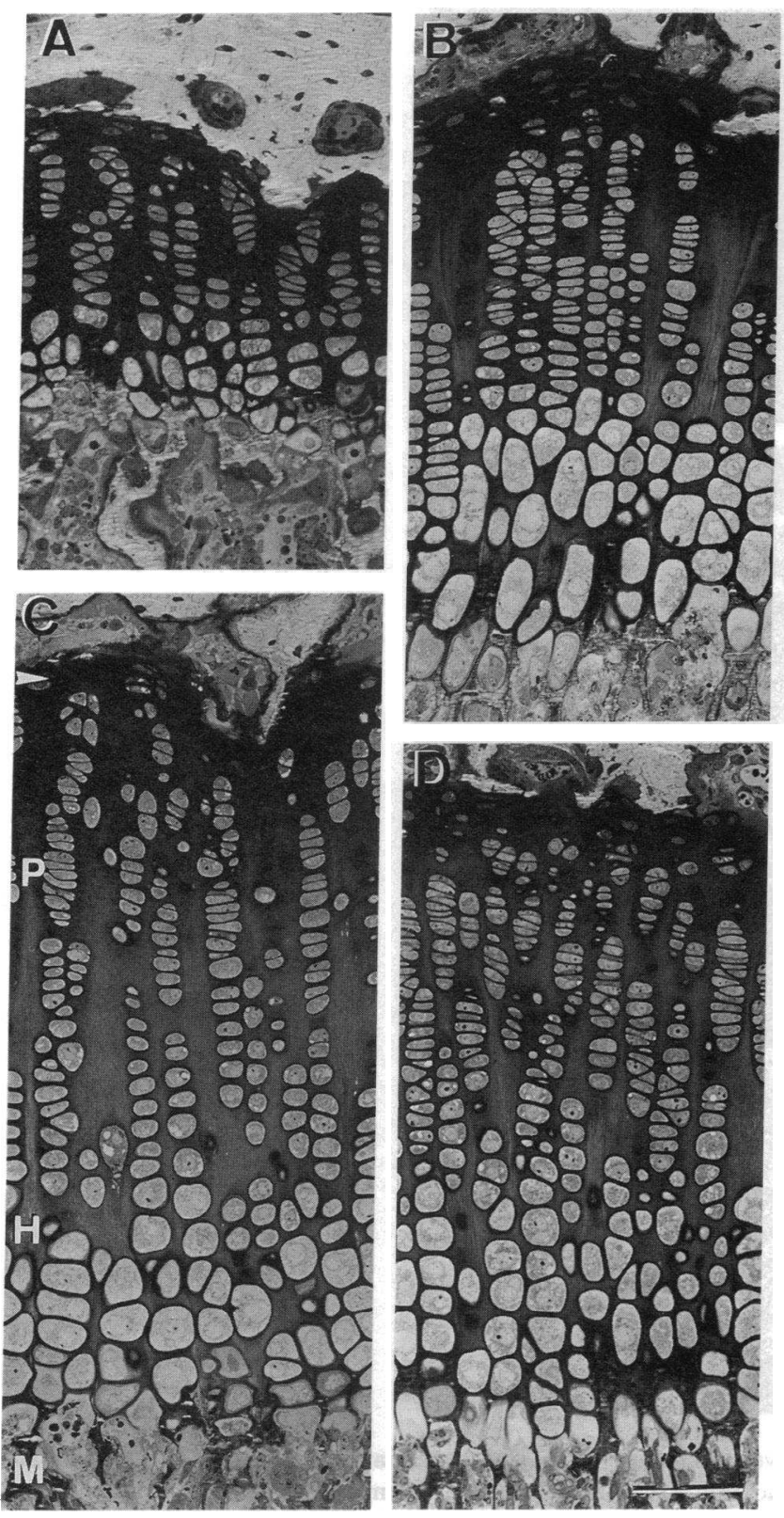

Figure 3. Growth plate structure. Light micrographs of vertical sections through the proximal tibial growth plates of hypophysectomized rats subcutaneously infused with $\mathrm{NaCl}(A), \operatorname{IGF}-\mathrm{I}(B)$, and $\mathrm{GH}(C)$; $D$ represents the normal (unhypophysectomized) animals. Down each vertical column, chondrocytes run through a well-defined series of differentiation and activity phases: from the resting (arrowhead), through the proliferative $(P)$, to the hypertrophic $(H)$ cell stage. Growth plate heights of $\mathrm{NaCl}, \mathrm{GH}$, and normal rat groups differed significantly from one another; IGF-I and normal rat group heights were the same. Thick $(1-\mu \mathrm{m})$ sections stained with toluidine blue 0 . $M$, zone of mineralization. $\times 150 . \mathrm{Bar}=80 \mu \mathrm{m}$.

subject to significant modulation is cell productivity. The major productivity parameters analyzed were increases in cell height (Fig. $2 D$ ) and cell volume (Fig. $2 E$ ) and net matrix production per unit of time (Fig. $2 F$ ). In the hypophysectomized control group, these values were reduced by a factor of $\sim 10$. Treatment with GH stimulated productivity levels at all stages; during the stem and proliferating phases, this was in the order of five- to sevenfold, and during hypertrophy three- to fourfold. IGF-1 was less effective; it induced an approximately fourfold increase in productivity at the stem and proliferating stages, and a twofold one during hypertrophy.

\section{Discussion}

It was the aim of this study to establish precisely at which stages of chondrocyte differentiation and upon which cell parameter(s) IGF-I and GH act in vivo. The clear-cut stimulatory effects of IGF-I and GH upon body and organ weights and on growth rates underline their potential and effectiveness (Table II, reference 20) in hypophysectomized animals. It is worth noting that growth plate height, when used as the sole parameter to quantitate effects on skeletal growth, may be misleading since it does not change in proportion to growth rate (Table II, reference 3). Under physiological conditions, cell hypertrophy has been shown to be the most efficient cellular process contributing to bone elongation. Its essential role in regulating growth rate is achieved by controlled modulation of cell shape $(3,4$, 24). In this respect, it is important to note that both IGF-I and GH stimulated structural parameters of chondrocyte proliferation and hypertrophy maximally relative to normal rats (Fig. 1), despite the significantly different growth rates (Table II). The disparities in growth rate are, therefore, not attributable to modulations in cell structural characteristics, but rather to differences in cell kinetics and cell productivity per unit of time. The relative increases in growth rate induced by IGF-I and GH are paralleled by proportional increases in cell activity from one differentiation stage to the next, encompassing the stem cell to the terminal hypertrophic phases (Fig. 2). These findings indicate that both IGF-I and GH exert their influences at each stage of differentiation rather than acting specifically upon particular subpopulations of cells at certain phases of chondrocyte differentiation, as postulated in the "dual effector theory" $(17,18,30)$.

Although the same final structural parameters were attained with both hormones at the stem cell, proliferative, and hypertrophic phases (Fig. 1), GH completed structural changes within shorter periods of time (Fig. $2 A$ ). In all four experimental groups, parameters of cell productivity per unit of time (Fig. 2, $D-F$ ) were inversely proportional to cell cycle times (phase duration) (Fig. $2 \mathrm{~A}$ ). The quantitative differences between IGF-I and GH action do not argue against the large body of experimental evidence indicating that $\mathrm{GH}$ effects on chondrocytes are mediated by IGF-I, although they suggest that this is not an exclusive pathway. These quantitative differences could, at least in part, also be explained by the different modes of action and effectiveness of systemic and locally produced IGF-I. IGF-I infused into hypophysectomized rats circulates mainly in the form of a $40-\mathrm{kD}$ IGF-I-binding protein complex, whereas IGF-I induced by $\mathrm{GH}$ infusion is predominantly bound within a $150-\mathrm{kD}$ heterotrimeric binding protein complex $(22,31)$. In contrast to the $40-\mathrm{kD}$ form, the bioavailability of IGF-I in the $150-\mathrm{kD}$ form is largely restricted by its limited capillary permeability $(32,33)$. Therefore, these two systemic forms of IGF-I are unlikely to cause the same growth effects. Hence, it must be stressed that the difference in circulating IGF-I levels effected under GH and IGF-I infusion con- 

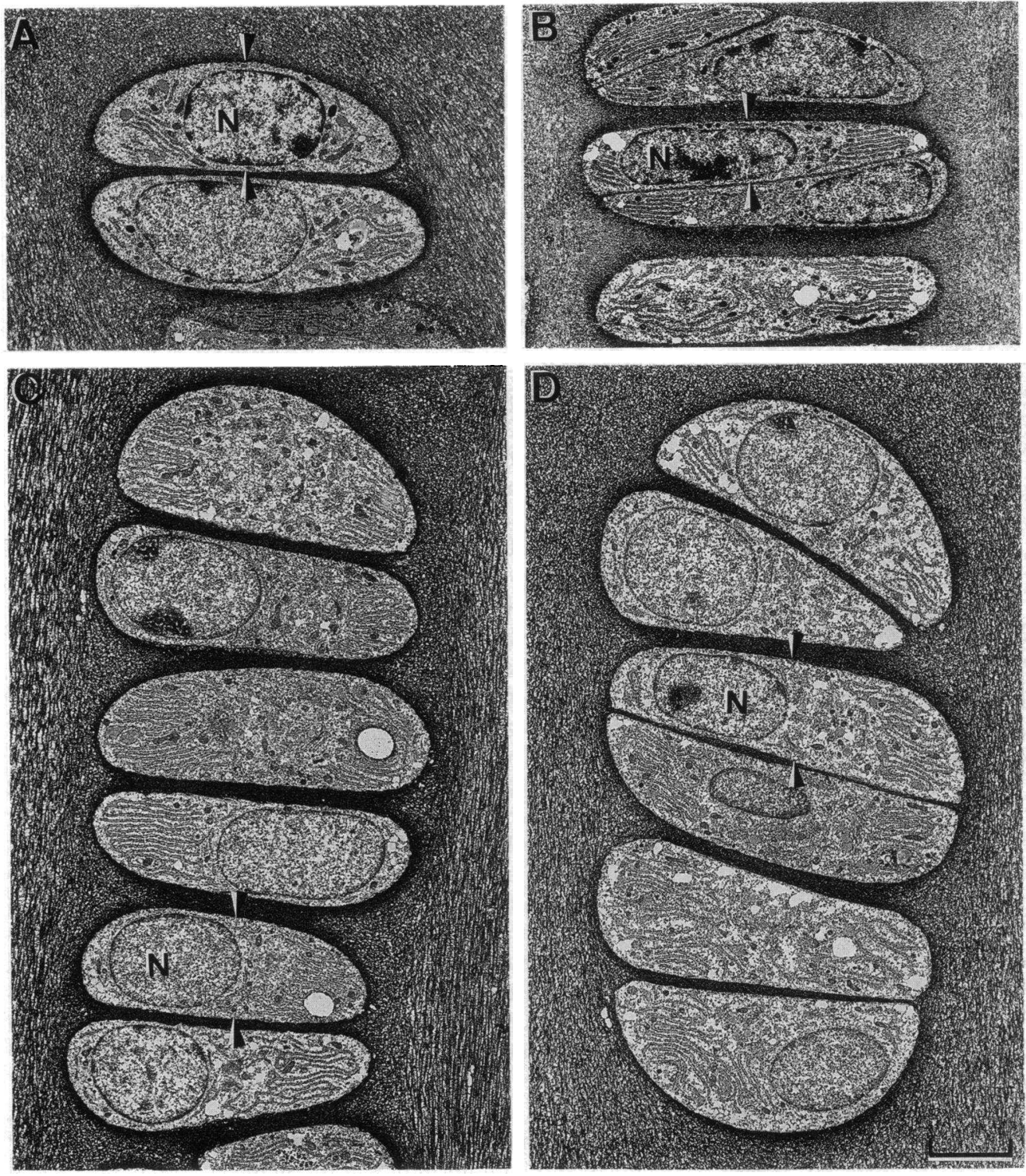

Figures 4 and 5. Chondrocyte structural changes. Electron micrographs of vertical sections through growth plate chondrocytes of the proximal tibia, at the proliferative (Fig. 4, above) and hypertrophic (Fig. 5, opposite) activity phases, from hypophysectomized rats subcutaneously infused with $\mathrm{NaCl}(B)$, IGF-I $(C)$, or hGH $(D) ; A$, normal (unhypophysectomized) rats. All pictures are represented at identical magnifications, and thus demonstrate the tremendous increase in cell height (arrowheads) and volume achieved during hypertrophy (in the order of 7 [height] and 8 [vol] times [except for the $\mathrm{NaCl}$ group, for which the corresponding values are 4 and 5]). However, the time periods required to achieve this phenotype transformation process differ significantly (1.2 d [normal rats]), $2.8 \mathrm{~d}$ [hGH], $4 \mathrm{~d}$ [ IGF-I], and $6 \mathrm{~d}[\mathrm{NaCl}])$. Thin sections stained with uranyl acetate and lead citrate. $N$, nucleus. Bar $=4 \mu \mathrm{m}$.

ditions cannot unequivocally account for quantitative differences in the action of the two hormones. The circulating form of exogenously administered IGF-I would be expected to be more effective than circulating IGF-I induced by $\mathrm{GH}$. On the other hand, GH induces IGF-I locally in growth plate chondrocytes (14-16), and locally produced IGF-I, acting immediately as a nascent signaling substance in an auto/paracrine manner, is probably more effective than the circulating $40-\mathrm{kD}$ form of IGF-I, which has to gain access to target cells via several diffusion barriers. Thus, in contrast to infused exogenous IGF-I, the effects of GH on chondrocyte differentiation stages are likely to be mediated predominantly by locally produced IGF-I. This is also compatible with the finding that cell-surface receptors for $\mathrm{GH}$, as well as for IGF-I, are present at all stages of differentiation in growth plate cartilage (34-36).

A most remarkable aspect of our in vivo study is that IGF-I acts not only at the proliferative phase, but is also capable of influencing chondrocyte differentiation via its effect on stem cells. This finding is supported by analogous data in vitro pertaining to osteoblast (37) and preadipocyte differentiation (38). Experiments using cultured growth plate chondrocytes have yielded conflicting results in this respect: some studies describe IGF-I acting selectively on the differentiated proliferating cell pool (5), whereas others report that all stages of 

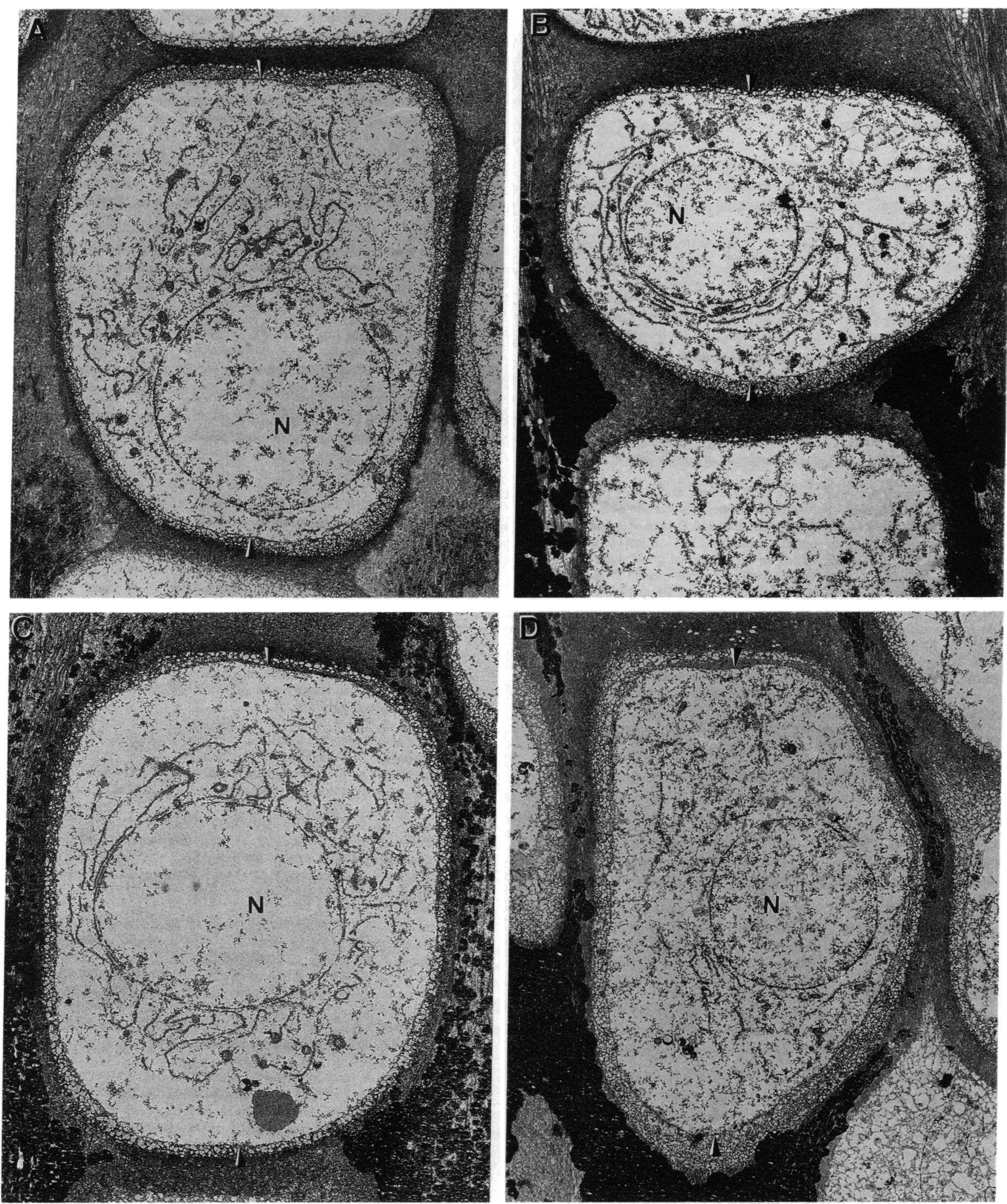

Figure 5

growth plate cell differentiation are responsive to this hormone, although to a varying degree (39-41). Moreover, contrary to general belief, the effects of IGF-I at the proliferative phase of activity are exerted primarily by a shortening of the cycle time rather than by clonal expansion, i.e., by increasing the cell pool size. All these findings underline that the hitherto 
applied dual effector theory relating to the mechanisms of action of IGF-I and GH on chondrocytes in vivo requires revision.

\section{Acknowledgments}

The authors thank R. Cortesi (Ciba-Geigy AG) for performing the hypophysectomies; Ch. Hauri for excellent technical assistance; V. Rickli for secretarial expertise; K. Jürgensen for help with the graphics; and $\mathrm{M}$. Paulsson for critical appraisal.

This work was supported by the Swiss National Science Foundation, grants 31-32509.91 and 32-31281.91, and by Ciba-Geigy AG.

\section{References}

1. Schoenle, E., J. Zapf, R. E. Humbel, and E. R. Froesch. 1982. Insulin-like growth factor I stimulates growth in hypophysectomized rats. Nature (Lond.). 296:252-253.

2. Isgaard, J. 1992. Expression and regulation of IGF-I in cartilage and skeletal muscle. Growth Regul. 2:16-22.

3. Hunziker, E. B., and R. K. Schenk. 1989. Physiological mechanisms adopted by chondrocytes in regulating longitudinal bone growth in rats. J. Physiol. (Lond.). 414:55-71.

4. Breur, G. J., B. A. VanEnkevort, C. E. Farnum, and N. J. Wilsman. 1991. Linear relationship between the volume of hypertrophic chondrocytes and the rate of longitudinal bone growth in growth plates. J. Orthop. Res. 9:348-359.

5. Lindahl, A., A. Nilsson, and O. G. Isaksson. 1987. Effects of growth hormone and insulin-like growth factor-I on colony formation of rabbit epiphyseal chondrocytes at different stages of maturation. J. Endocrinol. 115:263-271.

6. Trippel, S. B., M. T. Corvol, M. F. Dumontier, R. Rappaport, H. H. Hung, and H. J. Mankin. 1989. Effect of somatomedin-C/insulin-like growth factor I and growth hormone on cultured growth plate and articular chondrocytes. $\mathrm{Pe}$ diatr. Res. 25:76-82.

7. Böhme, K., M. Conscience-Egli, T. Tschan, K. H. Winterhalter, and P. Bruckner. 1992. Induction of proliferation or hypertrophy of chondrocytes in serum-free culture. The role of insulin-like growth factor-I, insulin, or thyroxine. J. Cell Biol. 116:1035-1042.

8. Salmon, W. D., and W. H. Daughaday. 1957. A hormonally controlled serum factor which stimulates sulfate incorporation by cartilage in vitro. J. Lab. Clin. Med. 49:825-836.

9. Daughaday, W. H., K. Hall, M. S. Raben, W. D. Salmon, J. L. Van den Brande, and J. J. Van Wyk. 1972. Somatomedin: proposed designation for sulphation factor. Nature (Lond.). 235:107.

10. McConaghy, P., and C. B. Sledge. 1970. Production of sulphation factor by the perfused liver. Nature (Lond.). 225:1249.

11. Daughaday, W. H. 1989. A personal history of the origin of the somatomedin hypothesis and recent challenges to its validity. Perspect. Biol. Med. 32:194 211.

12. Isaksson, O. G., J. O. Jansson, and I. A. Gause. 1982. Growth hormone stimulates longitudinal bone growth directly. Science (Wash. DC). 216:12371239.

13. Schlechter, N. L., S. M. Russell, S. Greenberg, E. M. Spencer, and C. S. Nicoll. 1986. A direct growth effect of growth hormone in rat hindlimb shown by arterial infusion. Am. J. Physiol. 250:E231.

14. Schlechter, N. L., S. M. Russell, E. M. Spencer, and C. S. Nicoll. 1986. Evidence suggesting that the direct growth-promoting effect of growth hormone on cartilage in vivo is mediated by local production of somatomedin. Proc. Natl. Acad. Sci. USA. 83:7932-7934.

15. Trippel, S. B., H. H. Hung, and H. J. Mankin. 1987. Synthesis of somatomedin-C by growth plate chondrocytes. Orthop. Trans. 11:422.

16. Isgaard, J., C. Muller, O. G. P. Isaksson, A. Nilsson, L. S. Matthews, and G. Norstedt. 1988. Regulation of insulin-like growth factor messenger ribonucleic acid in rat growth plate by growth hormone. Endocrinology. 122:1515.

17. Green, H., M. Morikawa, and T. Nixon. 1985. A dual effector theory of growth-hormone action. Differentiation. 29:195-198.

18. Ohlsson, C., A. Nilsson, O. Isaksson, and A. Lindahl. 1992. Growth hormone induces multiplication of the slowly cycling germinal cells of the rat tibial growth plate (epiphyseal plate). Proc. Natl. Acad. Sci. USA. 89:9826-9830.

19. Greenspan, F. S., C. H. Li, M. E. Simpson, and H. M. Evans. 1949 Bioassay of hypophyseal growth hormone: the tibia test. Endocrinology. 45:455463.

20. Guler, H. P., J. Zapf, E. Scheiwiller, and R. Froesch. 1988. Recombinant human insulin-like growth factor I stimulates growth and has distinct effects on organ size in hypophysectomized rats. Proc. Natl. Acad. Sci. USA. 85:4889-4893.
21. Zapf, J., H. Walter, and E. R. Froesch. 1981. Radioimmunological determination of insulinlike growth factors I and II in normal subjects and in patients with growth disorders and extrapancreatic tumor hypoglycemia. J. Clin. Invest. 68:1321-1330.

22. Zapf, J., C. Hauri, M. Waldvogel, E. Futo, H. Hasler, K. Binz, H. P. Guler, and E. R. Froesch. 1989. Recombinant human insulin-like growth factor I induces its own specific carrier protein in hypophysectomized and diabetic rats. Proc. Natl. Acad. Sci. USA. 86:3813-3817.

23. Cruz Orive, L. M., and E. B. Hunziker. 1986. Stereology for anisotropic cells: application to growth cartilage. J. Microsc. (Oxf.). 143:47-80.

24. Hunziker, E. B., R. K. Schenk, and L. M. Cruz Orive. 1987. Quantitation of chondrocyte performance in growth-plate cartilage during longitudinal bone growth. J. Bone Jt. Surg. Am. Vol. 69:162-173.

25. Hunziker, E. B., and R. K. Schenk. 1984. Cartilage ultrastructure after high pressure freezing, freeze substitution, and low temperature embedding. II. Intercellular matrix ultrastructure-preservation of proteoglycans in their native state. J. Cell Biol. 98:277-282.

26. Gundersen, H. J., T. F. Bendtsen, L. Korbo, N. Marcussen, and A. Moller. 1988. Some new, simple and efficient stereological methods and their use in pathological research and diagnosis. APMIS (Acta Pathol. Microbiol. Immunol. Scand.). 96:379-394.

27. Hansson, L. I. 1967. Daily growth in length of diaphysis measured by oxytetracycline in rabbit normally and after medullary plugging. Acta Orthop. Scand. Suppl. 101:1-199.

28. Kember, N. F. 1971. Cell population kinetics of bone growth: the first ten years of autoradiographic studies with tritiated thymidine. Clin. Orthop. Rel. Res. 76:213-230.

29. Walker, K. V., and N. F. Kember. 1972. Cell kinetics of growth cartilage in the rat tibia. I. Measurements in young male rats. Cell Tissue Kinet. 5:401-408.

30. Isaksson, O. G., A. Nilsson, J. Isgaard, and A. Lindahl. 1990. Cartilage as a target tissue for growth hormone and insulin-like growth factor I. Acta Paediatr. Scand. Suppl. 367:137-141.

31. Baxter, R. C., and J. L. Martin. 1989. Structure of the Mr 140000 growth hormone-dependent insulin-like growth factor binding protein complex: determination by reconstitution and affinity labeling. Proc. Natl. Acad. Sci. USA. 86:6898-6902.

32. Binoux, M., and P. Hossenlopp. 1988. Insulin-like growth factor (IGF) and IGF binding proteins: comparison of human serum and lymph. J. Clin. Endocrinol. \& Metab. 67:509-514.

33. Guler, H. P., J. Zapf, C. Schmid, and E. R. Froesch. 1989. Insulin-like growth factors I and II in healthy man: estimation of half-lives and production rates. Acta Endocrinol. 121:753-758.

34. Trippel, S. B., J. J. Van Wyk, M. B. Foster, and M. E. Svoboda. 1983. Characterization of a specific somatomedin-c receptor on isolated bovine growth plate chondrocytes. Endocrinology. 112:2128-2136.

35. Barnard, R., K. M. Haynes, G. A. Werther, and M. J. Waters. 1988. The ontogeny of growth hormone receptors in the rabbit tibia. Endocrinology 122:2562-2569.

36. Werther, G. A., K. M. Haynes, R. Barnard, and M. J. Waters. 1990. Visual demonstration of growth hormone receptors on human growth plate chondrocytes. J. Clin. Endocrinol. \& Metab. 70:1725-1731.

37. Schmid, C., T. Steiner, and E. R. Froesch. 1984. Insulin-like growth factor I supports differentiation of cultured osteoblast-like cells. FEBS (Fed. Eur. Bio chem. Soc.) Lett. 173:48-52.

38. Smith, P. J., L. S. Wise, R. Berkowitz, C. Wan, and C. S. Rubin. 1988. Insulin-like growth factor-I is an essential regulator of the differentiation of 3T3 L1 adipocytes. J. Biol. Chem. 263:9402-9408.

39. Hill, D. J. 1979. Stimulation of cartilage zones of the calf costochondral growth plate in vitro by growth hormone dependent rat plasma somatomedin activity. J. Endocrinol. 83:219-227.

40. Makower, A. M., J. Wroblewski, and A. Pawlowski. 1988. Effects of IGFI, EGF, and FGF on proteoglycans synthesized by fractionated chondrocytes of rat rib growth plate. Exp. Cell Res. 179:498-506.

41. Makower, A. M., A. Skottner, and J. Wroblewski. 1989. Binding of insulin-like growth factor-I (IGF-I) to primary cultures of chondrocytes from rat rib growth cartilage. Cell Biol. Int. Rep. 13:655-665.

42. Burch, W. M., and K. S. J. McCarty. 1984. Hormonal stimulation of avian embryonic cartilage growth in vitro: histologic and ultrastructural features. In Vitro (Rockville). 20:329-338.

43. Quarto, R., G. Campanile, R. Cancedda, and B. Dozin. 1992. Thyroid hormone, insulin, and glucocorticoids are sufficient to support chondrocyte differentiation to hypertrophy. A serum-free analysis. J. Cell Biol. 119:989-995.

44. Lewinson, D., Z. Harel, P. Shenzer, M. Silbermann, and Z. Hochberg. 1989. Effect of thyroid hormone and growth hormone on recovery from hypothyroidism of epiphyseal growth plate cartilage and its adjacent bone. Endocrinology. 124:937-945.

45. Kavumpurath, S., and B. K. Hall. 1990. Lack of either chondrocyte hypertrophy or osteogenesis in Meckel's cartilage of the embryonic chick exposed to epithelia and to thyroxine in vitro. J. Craniofacial Genet. Dev. Biol. 10:263-275. 